\title{
Original
}

\section{He-Ne Laser Effect on Hard Tissue Formation in Osteoblastic Cells}

\author{
Keiko YAMADA, Chika HAYASHI, Kano KOEDA \\ and Kikuo KAMIYAMA \\ Department of Pedodontics, Tohoku University, School of Dentistry* \\ (Chief : Prof. Kikuo KAMIYAMA) \\ (Accepted for Publication: January 31, 1994)
}

\section{骨芽細胞様細胞の硬組織形成に及ぼすへリウムネオン \\ レーザーの影響について}

\author{
山田恵子林 千佳小枝佳乃 \\ 神山紀久男 \\ 東北大学歯学部小児歯科学講座 \\ (主任 : 神山紀久男教授) \\ (受理: 平成 6 年 1 月 31 日)
}

要旨：ラット頭蓋冠より分離，株化した骨芽細胞様細胞（MC3T3-E1）飞短時間（3 分間， 5 分間）の He$\mathrm{Ne} レ$ レ゙ーを照射した時の細胞の増殖に与える影響と, 細胞の無機質形成能の変化を調べるために実験を 行い, 次の結果を得た。

1）レーザー照射 1 日後， 3 日後，8 日後の細胞の形態を光顕下で観察したところ, 非照射細胞のそれと の違いは見られなかった。

2）非照射群，3 分間照射群，5 分間照射群に細胞の増殖能の違いは認められなかった。

3）レーザーを照射した細胞内外に蓄積したカルシウム量は, 非照射細胞のそれよりも有意に大きな值を 示した。

(J. Jpn. Soc. Laser Dent. $5: 35 \sim 40,1994$ Reprint requests to Dr. Yamada)

Key Words $=$ He-Ne laser : Calcium accumulation : MC3T3-E1

キーワード=ヘリウムネオンレーザー : カルシウム蓄皘 : MC3T3-E1

\section{Introduction}

The effects of laser irradiation on hard tissue have been repoted in medicine and dentistry. Several reports demonstrated that low power laser accelerated bone regeneration in vivo experiments $^{1-3)}$.

Motomura ${ }^{4)}$ reported that He-Ne laser is the best to accelerate callus formation compared with dye or $\mathrm{CO}_{2}$ laser. $\mathrm{Kon}^{3)}$ described that He-Ne laser ir-

* 4-1 Seiryo-machi, Aoba-ku, Sendai 980, Japan TEL 022-274-1111 (Ext 3330) FAX 022-271-1603

* 干980 仙台市青葉区星陵町 4-1 TEL 022-274-1111（内線 3330） FAX 022-271-1603 
radiation on artificial bone defects of rat carvaria enhanced new bone formation and it could induce from acceleration of bone cell proliferation by laser irradiation. Recently, some papers published to demonstrate the biological effect of low power laser on cells. Yamada ${ }^{5)}$ reported that cell growth and DNA synthesis of clonal osteoblastic cells (MC3T3-E1) were enhanced by He-Nelaser irradiation. On the other hand, J. Rigau et al. ${ }^{6)}$ demonstrated that fibroblasts were not increased by HeNe laser irradiation but the metabolism was activated. It is supposed that if the cell growth was accelerated by laser irradiation, bone tissue formation should be enhanced. However, it should be more important to investigate that whether the differentiation of bone tissue formation in an osteoblastic cell is activated or not by low power laser irradiation.

The purpose of the present study was to investigate the mineral formation effect of $\mathrm{He}-\mathrm{Ne}$ laser on clonal osteoblastic cells (MC3T3-E1) when the cells were exposed to $\mathrm{He}-\mathrm{Ne}$ laser with short duration time of 3 minutes or 5 minutes.

\section{Materials and Methods}

\section{Cell Culture and Laser Irradiation}

Clonal osteoblastic cells called MC3T3-E1 were used for this study. The cells were grown in alpha modification of Eagle's medium supplemented with $10 \%$ fetal bovine serum, $1 \%$ of penicillinstreptomycin-fungizone and $5 \mathrm{mM} \beta$-glycerophosphate at $37^{\circ} \mathrm{C}$ in an atmosphere of $5 \% \mathrm{CO}_{2}$ in humidified air. They were subcultured every three days using $0.1 \%$ trypsin with $0.02 \%$ EDTA in $\mathrm{Ca}^{2+}, \mathrm{Mg}^{2+}$ free phosphate buffered saline (PBS-). Cells were seeded on $35 \mathrm{~mm}$ plastic dishes at a density of $5 \times 10^{4} /$ dish for the present experiment. After culture of cells under the same condition for 2 - 3 hours, He-Ne laser (World Wide Laser Industry, $632.8 \mathrm{~nm}$ of wavelength, $6 \mathrm{~mW}$ of output energy) was irradiated for 3 or 5 minutes ( 114.3 $\mathrm{mJ} / \mathrm{cm}^{2}$ or $187.2 \mathrm{~mJ} / \mathrm{cm}^{2}$ ) from the bottom of $\mathrm{di}$ shes. Thereafter, they were placed in an incubator under the same condition to be followed by three kinds of experiments.

Experiment 1: Microscopic Observation on Morphological Change
Cell cultures were observed under an inverted phase contrast microscope (DIAPHOTO-TMD, NIKON) at the time of 2-3 hours, a day, three days and eight days after laser irradiation.

Cells were seeded for the control at the same time without laser irradiation under same condition as irradiated cells.

Experiment 2: Determination of cell numbers

At every 24 hours after laser irradiation, the medium was discarded and the cells were washed twice with $\mathrm{PBC}(-)$. Cells were dispersed with 0.1 $\%$ trypsin with $0.02 \%$ EDTA in PBS and centrifuged at 1000 r.p.m. for five minutes and cell numbers were counted by trypan blue exclusion test on a hemocytometer.

\section{Experiment 3: Accumulated calcium assay}

On every seventh day during four weeks, the medium was discarded and the cells were washed with calcium and magnesium free PBC. They were then scraped intoa porcelain cruicible with a rubber-policeman and were left at room temperature to be dried naturally. The porcelain crucible were placed in a muffle furnace at $700^{\circ} \mathrm{C}$ for 24 hours to burn all kinds of organic matters and obtain only minerals. The ash was dissolved in $1 \mathrm{ml}$ of $15 \% \mathrm{HCl}$ and then $0.5 \mathrm{ml}$ of the solution was diluted with $3.5 \mathrm{ml}$ of deionized water as well as $1 \mathrm{ml}$ of $0.1 \mathrm{~N} \mathrm{HCl}$ included $6250 \mathrm{ppm}$ Strontium. Thereafter, stable calcium in the solution mas measured with an atomic absorption spectrophotometer (HITACHI 180).

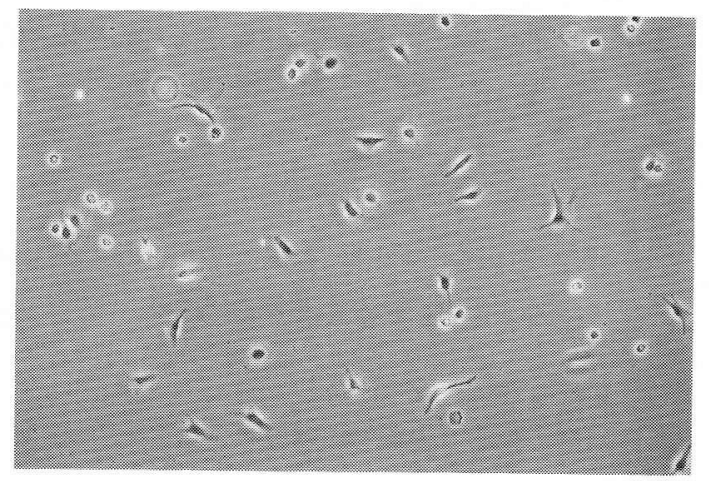

Fig. 1 Photomicrograph of MC3T3-E1 cells $(\times 100)$

Cells are attached to the bottom of dishes and their processes just started to extend 2-3 hours after being seeded. 


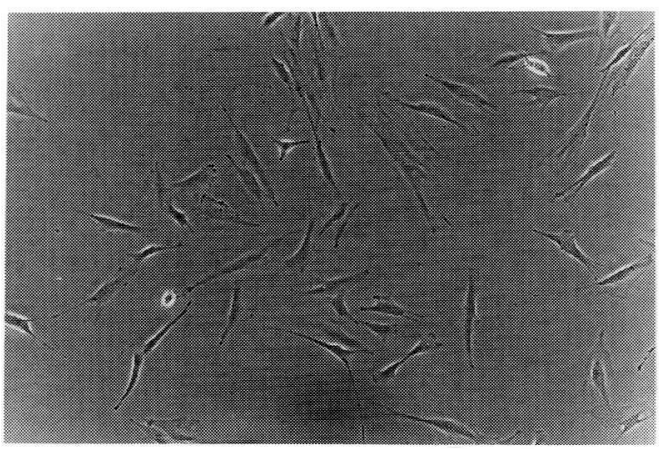

Fig. 2

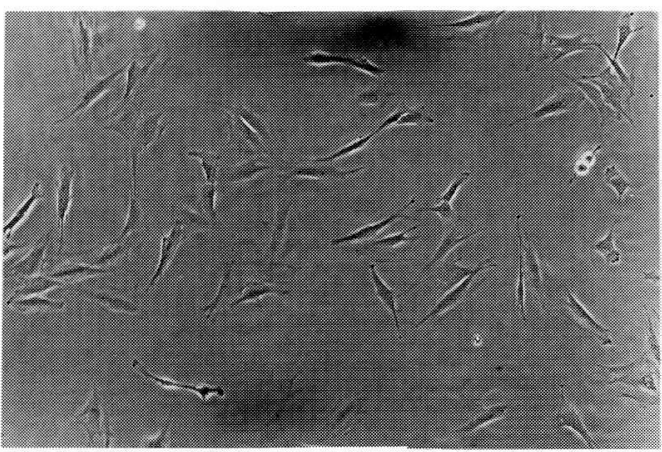

Fig. 3

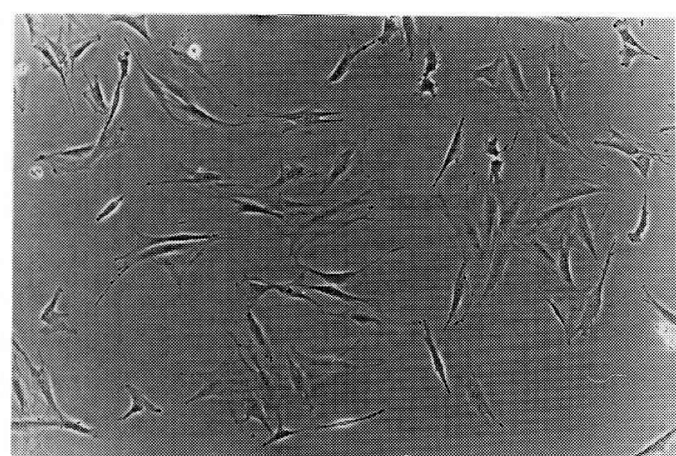

Fig. 4

Fig. 2-4 Photomicrographs of MC 3T3-E1 cells $(\times 100)$

(24 hours after laser irradiation) 2 ; Control, 3 ; 3 min Lased, 4 ; 5 min Lased

Cells showed spindle-shaped morphology in any culture.

\section{Results}

\section{Microscopic Observation}

The most number of cells attached to bottom of

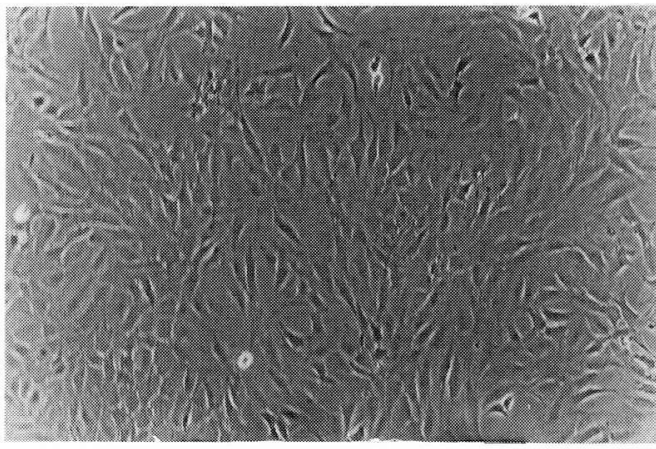

Fig. 5

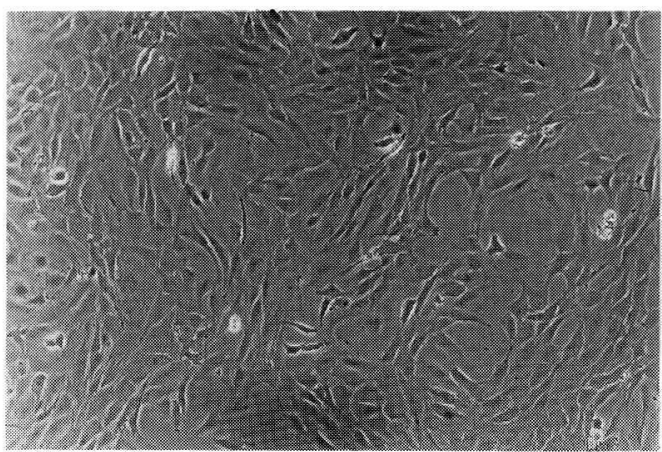

Fig. 6

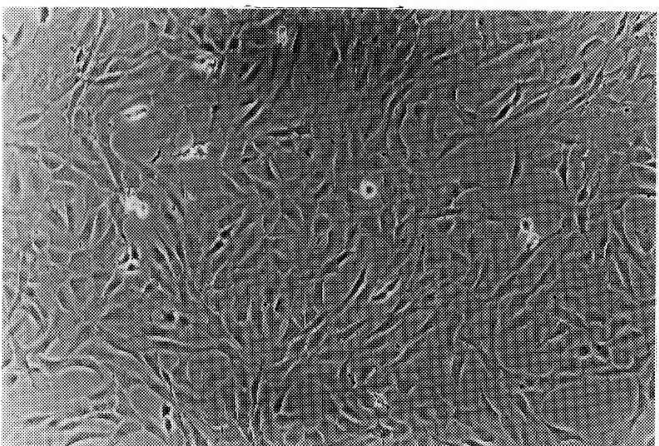

Fig. 7

Fig. 5-7 Photomicrographs of MC 3T3-E1 cells $(\times 1000)$

(3 days after irradiation)

5 ; Control, 6 ; $3 \mathrm{~min}$ Lased, 7 ; 5 min Lased

The density of cells increased equally in each culture, and the processes showed longer compared with Fig. 2-4.

dishes and started to eptending their processes in 2-3 hours after they had been seeded (Fig. 1), and then $\mathrm{He}-\mathrm{Ne}$ laser irradiated to cells from bottom of dishes at the time. 


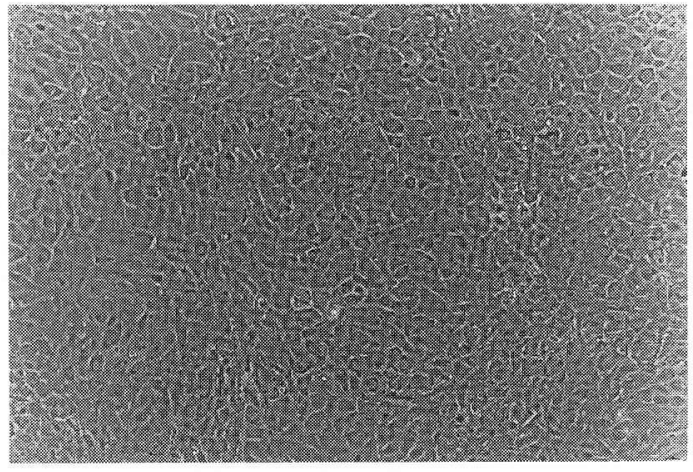

Fig. 8

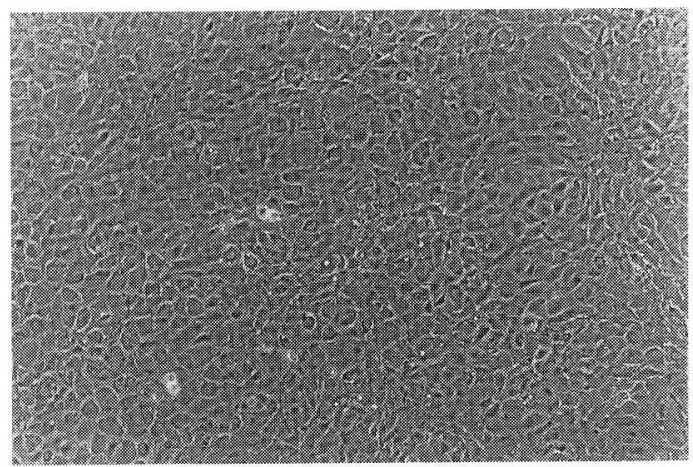

Fig. 9

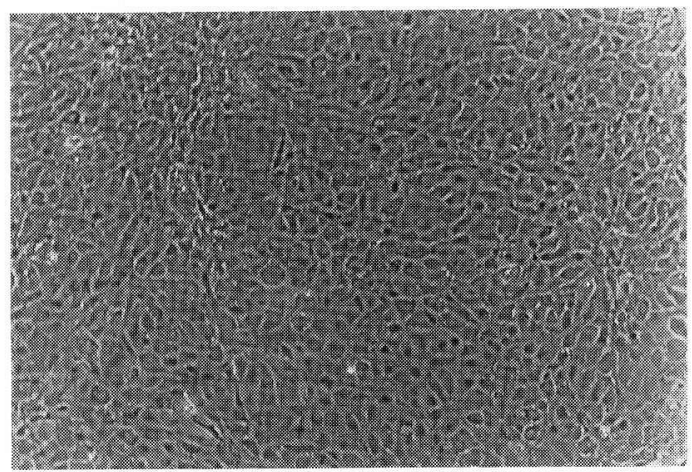

Fig. 10

Fig. 8-10 Photomicrographs of MC 3T3-E1 cells $(\times 100)$

( 8 days after irradiation)

8; Control, $9: 3 \mathrm{~min}$ Lased, 10 ;

$5 \mathrm{~min}$ Lased

Cells are seemed tob be in confluent and showed round-shaped morphology.

Irradiated cells showed spindle- shaped morphology on one day after irradiation and it was not different from the morphology of unirradiated cells on one day after they had been seeded (Fig. 2, $3,4)$. On 3 days after laser irradiation, the density

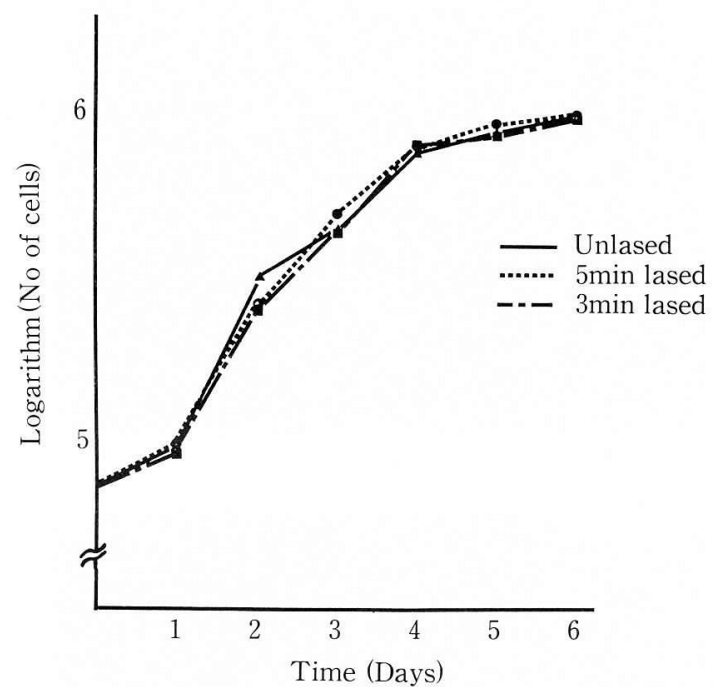

Fig. 11 Cell Proliferation (Logarithm No of cells/ dish)

of cells increased equally in 3 minutes, 5 minutes irradiated or unirradiated cultures. The morphology in each cells were not different (Fig. 5, $6,7)$. Cells were seemed to be in confluent on the 8 day culture and round-shaped in irradiated cells as well as control cells (Fig. 8, 9, 10).

\section{Cell Proliferation}

Mean numbers and S. D. of cells according to culture time are shown in Table 1 and the logarithms of the cell numbers are shown in Fig. 11. The numbers of irradiated cells ( 3 or 5 minutes of duration) were not different from unirradiated cells at any day. The number of cells increased rapily from 1 through 4 days after irradiation, but the speed of proliferation was slow down at 4 th day through 6th day.

\section{Accumulated Calcium Assay}

The mean amounts of calcium which was accumulated in irradiated or unirradiated cultures were shown in Table 2 and Fig. 12. The amounts of calcium accumulated inside and outside of cells during $1,3,4$, weeks after 5 minute irradiation were higher than the calium accumulation in 3 minute irradiated or unirradiated cell cultures at the respective periods. The amounts of calcium in 3 minutees irradiated cell cultures were not significantly different with unirradiated cell cultures at any periods. 
Table 1 The mean number of cells according to

\begin{tabular}{|c|c|c|c|}
\hline Days & Control & $3 \mathrm{~min}$. Lased & $5 \mathrm{~min}$. Lased \\
\hline 1 & $8.5(0.7)$ & $8.6(0.4)$ & $7.8(0.8)$ \\
\hline 2 & $21.3(2.1)$ & $18.0(2.2)$ & $17.7(1.9)$ \\
\hline 3 & $27.7(3.6)$ & $31.3(2.7)$ & $26.9(4.4)$ \\
\hline 4 & $59.0(5.7)$ & $64.7(1.3)$ & $63.3(9.8)$ \\
\hline 5 & $76.7(9.9)$ & $70.0(6.5)$ & $70.7(4.2)$ \\
\hline 6 & $113.3(26.2)$ & $103.0(21.3)$ & $106.3(12.0)$ \\
\hline
\end{tabular}

(S.D.)

The changes of cell numbers in each cultures are not different significantly.

Tabule 2 The amount of stable calcium in cultues $(\mu \mathrm{g} / \mathrm{dish})$

\begin{tabular}{|c|c|c|c|c|}
\hline & 1 week & 2 week & 3 week & 4 week \\
\hline Control & $7.6(0.93) \square_{* *}$ & $11.6(0.22) \square$ & $12.2(0.21) \square$ & $15.6(0.85) \square$ \\
\hline 3 min. Lased & $8.2(1.22) \square_{*}$ & $11.6(0.36)$ * & $13.1(2.08) \quad * *$ & $18.2(1.31)$ *** \\
\hline 5 min. Lased & $14.5(0.14) \perp^{*}$ & $14.6(1.11)-$ & $15.2(0.90)-$ & $21.9(0.46) \perp^{*}$ \\
\hline
\end{tabular}

The mean anount of stable calcium accumulated in cultures which were exposed to laser for 5 minutes were different from calcium amount of control culture at the time of 1,3 and 4 weeks after laser irradiation.

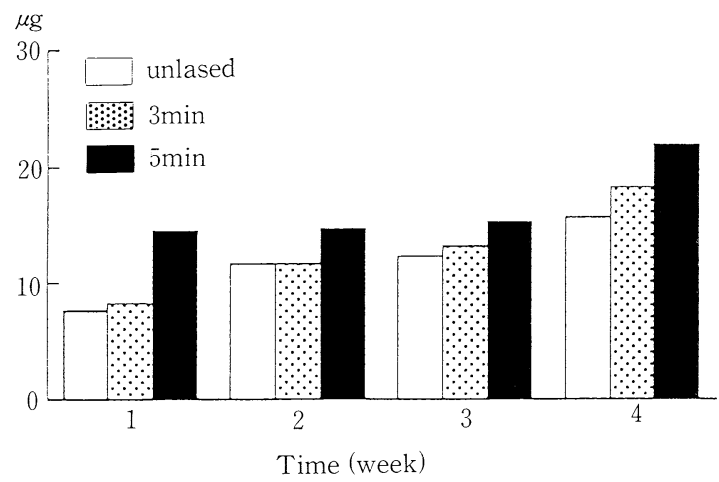

Fig. 12 Calcium Accumulation $(\mu \mathrm{g} /$ dish)

\section{Discussion}

It is known that wound healing and bone regeneration are accerelated by low power laser irradiation in vivo. Especially, $\mathrm{He}-\mathrm{Ne}$ laser is most popular in clinical application. Trellas and Mayayo ${ }^{1)}$ observed an important increase in vascularization and faster formation of osseous tissue with a dense trabecular net in the tibia of mice which was exposed by $\mathrm{He}-\mathrm{Ne}$ laser radiation compared to the control group. On the other hand, several authors have described that cell proliferat- ion and differentiation were activated by low power laser irradiation to fibroblast or osteoblastic cells. In respect of laser effect on cell proliferation, however, the findings are different among papers and it seems to depend on the setting condition of cells, output energy and the kind of laser apparatus.

On the present study, low output energy (114.3 $\mathrm{mJ} / \mathrm{cm}^{2}$ or $187.2 \mathrm{~mJ} / \mathrm{cm}^{2}$ ) was applied to osteoblastic cells to focus on the laser effect on the cell function of bone tissue formation, not on the proliferation of cells. As a result, cell growth was not accelerated, but calcium accumulation was increased by the laser irradiation under the setting condition compared to unirradiated cells.

From this point, enhancement of calcium accumulation inside and outside of MC3T3-E1 cells seemed to be induced from functional differentiation which was accerelated by $\mathrm{He}-\mathrm{Ne}$ laser irradiation. With the microscopic observation on cultured cells, the effect of $\mathrm{He}-\mathrm{Ne}$ laser irradiation on cell morphology was not observed as Yamada $^{7}$ reported no effect of $\mathrm{He}-\mathrm{Ne}$ laser irradiation on RA cellmorphology as well as osteo- 
blastic cells ${ }^{5)}$.

Schreider et al. ${ }^{8)}$ demonstrated that enhancement of Golgi apparatus in fibroblast which was exposed to He-Ne laser beam had recognized under TEM observation. It is known that the Golgi body includes microfibers and microgranules and it participates the formation of collagen as well as polysaccharides ${ }^{9)}$.

On the other hand, it has been reported that low power laser accelerated collagen synthesis in fibloblast ${ }^{10,11)}$.

It seems to be the possibility of the mechanism of laser effects on hard tissue formation in osteoblastic cells that the low power laser stimulates procollagen synthesis in osteoblastic cells and collagen synthesis as well as calcification in and outside of cells.

\section{Conclusion}

He-Ne laser stimulates differentiation of osteoblastic cells (MC3T3-E1) for hard tissue formation even if the duration of the laser is too short to accerelate cell proliferation.

The outline of this paper was reported on $3 \mathrm{rd}$ International Congress on Laser in Dentistry (Salt Lake Sity, August, 1992).

\section{Acknowledgement}

Authors would like to thank Dr. K. Igarashi (Dept. of Orthodontics, Tohoku University School of Dentistry) for kindly providing MC3T3-E1 cells for the present study. This reserch was supported by Japanese Government (Grant number 04454517, 1992 1993).

\section{Reference}

1) M. A. Trellas and E. Mayayo: Bone Fracture Consolidates faster with low power laser; Lasers in Surgery and Medicine, $7: 36-45,1987$.

2) J.W. Chen and Y. C. Zhou: Effect of low level carbon dioxide laser irradiation on biochemical metabolism of rabbit mandibular bone callus; Laser Therapy, 1 : 83-87, 1989.

3) K. Kon: In vivo study of low power laser irradiation on new bone formation of rat carvania defect; J. Japan. Soc. for Laser Dentistry 3 : 35-44, 1992.

4) K. Motomura, M. Nakajima, A. Ihara and K. Atsumi : Effects of various laser irradiation on callus formation; The J. Japan Soc. for Laser Madicine, 4 : 195-196, 1984.

5) K. Yamada: Biological effect of low power laser irradiation on clonal osteoblastic cells (MC3T3-E1); J. Jpn. Orthop. Assoc. 65 : 787-799, 1991.

6) J. Rigau, M. A. Trellas, R. G. Calderhead and E. Mayayo: Changes in fibroblast proliferation and metabolism following in vitro helium-neon laser irradiation; Laser Therapy, 3 : 25-33, 1991.

7) K. Yamada, N. Matsui, T. Ohtsuka, M. Hattori and T. Kato: Effects of low power laser irradiation on DNA synthesis of cultured synovial cells from patients with RA ; The J. of Japan Soc. Sor Laser Medicine, 10 : 3-1 $0,1990$.

8) N. P. Schneider, A. Armed, M. Soundry, J. C. Franquin and P. M. Martin: Helium-neon laser treatment transforms fibroblasts into myofibroblasts; American J. of Patology, 137 : 171-178, 1990.

9) C. P. Leblond and M. Weinstock: Radioautographic studies of bone formation [Ed. by Bourre G. H.: The Biochmistry and Physiology of Bone Vo13, Development and Growth] 2 nd. Ed. Academic Press, New York, London, 181, 1971.

10) E. Meter, A. F. Mester and A. Mester: The biomedical effects of laser application; Lasers in Surgery and Medicine, $5: 31-39,1985$.

11) T. S. Lam, R. P. Abergel, C. A. Meeker, J. C. Castel, R. M. Dwyer and J. Uitto: Laser stimulation of collagen synthesis in human skin fibroblast cultures; Lasers in the Life Sciencs, $1: 61-77,1986$. 